\title{
Histopathological lesions in central nervous system of goats poisoned by Ipomoea carnea
}

\author{
Ríos, E. ${ }^{1}$; Cholich, L. ${ }^{2}$; Silva, J. ${ }^{1}$; Acosta de Pérez, O. ${ }^{2}$ \\ ${ }^{1}$ Cátedra de Grandes Animales, ${ }^{2}$ Cátedra de Farmacología, Facultad de Ciencias Veterinarias, UNNE, \\ Sargento Cabral 2139, Corrientes (3400), Argentina. Tel/Fax 03783-425753. \\ E-mail: patmed@vet.unne.edu.ar.
}

\begin{abstract}
Ríos, E.; Cholich, L.; Silva, J.; Acosta de Pérez, O.: Histopathological lesions in central nervous system of goats poisoned by Ipomoea carnea. Rev. vet. 19: 2, 130-134, 2008. Ipomoea carnea var. fistulosa (Convolvulaceae) is a perenne poisonous plant, found throughout the Argentine Northeastern. The intoxication produces a lysosomal storage disease in goats, sheep and cattle. Five goats were fed with $50 \mathrm{~g} / \mathrm{kgBW} /$ day of fresh leaves, flowers and stems of $I$. carnea, during 43-60 days. Hirsute coat, depression, difficulty to stand up, ataxia, hypermetria, wide-based stance, incoordination of muscular movements, intense tremors, spastic paresis, abnormal postural reactions, nystagmus, hyperreflexia, hypersensitivity to sound, head tilting and loss of equilibrium were observed in all treated animals. The histopathologic study revealed the presence of cytoplasmatic vacuolation mainly in medulla oblongata and cerebellum. Control animals did not show any alterations. We conclude that this poisoning causes central nervous system damage, being Purkinje cells the most severely affected.
\end{abstract}

Key words: goat, intoxication, Ipomoea carnea, nervous system lesions.

\begin{abstract}
Resumen
Ríos, E.; Cholich, L.; Silva, J.; Acosta de Pérez, O.: Lesiones histopatológicas en sistema nervioso central de cabras intoxicadas con Ipomoea carnea. Rev. vet. 19: 2, 130-134, 2008. Ipomoea carnea var. fistulosa (Convolvulaceae) es una planta tóxica, perenne, distribuida en el nordeste de Argentina. La intoxicación produce una enfermedad de almacenamiento lisosomal en cabras, ovejas y bovinos. Cinco cabras fueron tratadas vía oral con $50 \mathrm{~g} / \mathrm{kg} /$ día de hojas frescas, flores y tallos de I. carnea, durante 43-60 días. En todos los animales tratados se observó pelo hirsuto, depresión, dificultad en la estación, ataxia, hipermetría, aumento de la base de sustentación, incoordinación de movimientos, intensos tremores, paresia espástica, reacciones posturales anormales, nistagmo, hiperreflexia, hipersensibilidad a los sonidos, cabeza inclinada y pérdida de equilibrio. El estudio histopatológico reveló la presencia de vacuolización citoplasmática principalmente en medula oblonga y cerebelo. Los animales controles no mostraron anormalidades. Se concluye que la intoxicación por $I$. carnea provoca daños en el sistema nervioso central, resultando las células de Purkinje las más severamente afectadas.
\end{abstract}

Palabras clave: cabra, intoxicación, Ipomoea carnea, lesiones sistema nervioso.

\section{INTRODUCTION}

Ipomoea carnea var. fistulosa (Convolvulaceae) is a toxic plant, found throughout the Northeast of Argentina and other tropical and subtropical countries ${ }^{3,7}$. The poisoning occurs when different animal species, such as goats, sheeps and cattle, eat this plant especially in drought periods because it is one of the fewest plants that stays green ${ }^{16}$.

The intoxication produces lysosomal storage disease which is characterized by the inhibition of specific

Recibido: 14 julio 2008 / Aceptado: 17 setiembre 2008 lysosomal hydrolases enzymes, leading to accumulation of undigested macromolecules that derive from cellular components of lysosomes, showing lysosomal accumulation of incompletely processed oligosaccharides, loss of cellular function, and ultimately cell death 6,12 . The poisoning is characterized by cytoplasmic vacuolation in different organs cells, mainly of neuronal cells resulting in central nervous system (CNS) disfunction ${ }^{11}$.

The isolated toxic from the plant are two nortropane alkaloids, calystegines $\mathrm{B}_{1} \mathrm{~B}_{2} \mathrm{y} \mathrm{C}_{1}$, and indolizine alkaloid, swansonine. The calistegines show a potent lysosomal inhibitory activity $\alpha$ and $\beta$ galactosidases, 
and $\alpha$-glucosidase. In contrast, swansonine is known as a powerful inhibitor of lysosomal $\alpha$-manosidase ${ }^{1}$, $8-10,14,15,20$. In experimental studies the plant induces clinical signs similar to those observed in spontaneous cases: all animals show disorders of behavior and consciousness as well as abnormalities of gait, difficulty to stand up, abnormal posture, emaciation, symmetrical ataxia and posterior limbs paresis 2, 9,21 . Neurological signs vary in frequency, progression, and severity ${ }^{2}$.

The most prominent histological lesions found are the cytoplasmic vacuolation of neurons from central and peripheral nervous system, as well as loss of Purkinje cells of the cerebellum and neurons of the cerebellar nuclei. Cytoplasmic vacuoles are also observed in cells of various organs including pancreas, liver, kidney, testicle and ovary, to name but a few ${ }^{4}$. Other CNS associated lesions include axonal spheroids that are observed in the granular layer of the cerebellum, cerebellar white matter, cerebellar peduncles and cerebelar nuclei ${ }^{4}$. Astrogliosis and neuropil microcavitation in the white matter are also present ${ }^{2}$.

The purpose of this study was to describe the microscopic lesions in experimental I. carnea toxicosis in goats taking into account that this type of study was not done in Argentina.

\section{MATERIAL AND METHODS}

Plant identification. I. carnea from Corrientes, Argentina, was collected in autumn. Samples of the plant were sent for taxonomic identification to the Instituto de Botánica, Facultad de Ciencias Agrarias, Universidad Nacional del Nordeste (Corrientes, Argentina).

Experimental intoxication. Five goats from both sexes, nearly 1-3 years old, which had not been previously exposed to the plant, received daily oral doses of $50 \mathrm{~g} / \mathrm{kg}$ body weight of fresh leaves, flowers and stems of I. carnea, during 43-60 days and additional amount of ground alfalfa. Four controls animals were fed only with ground alfalfa. In both groups water was administered ad libitum. Prior to the trial, goats were weighed and dewormed via subcutanea with ivermectin $200 \mathrm{mg} / \mathrm{kg}$.

Controls. Through the consumption period, animals were weighed weekly, and feed intake was monitored. Clinical examinations were performed weekly until the first signs of disease were observed. Thereafter, the animals were observed daily. The physical appearance, condition of feces and urine, respiratory rate, heart rate, rate of ruminal contraction, and body temperature were recorded. Special attention was given to the following parameters: behavior, consciousness, movement, postural reaction, cranial nerve function, spinal reflexes, and pain sensation.

The animals were euthanized and necropsied immediately after presenting severe intoxication signs, using a combination of high intravenous doses the xylacine, ketamine and sodium thiopental.

Histopathology. For the histological examinations, samples were collected inmediately after euthanasia.
Cerebellum and medulla oblongata were fixed in $10 \%$ formol, embedded in paraffin, secctioned at $5 \mu \mathrm{m}$ thickness, and stained with hematoxylin and eosin (H\&E).

\section{RESULTS}

The plant was identified as I. carnea, Convolvulaceae family, known with the common names of "mandiyura" or "aguapei" (Figure 1). I. carnea was toxic for goats. All animals of experimental group showed the first clinical signs after 39 day of daily ingestion of 50 $\mathrm{g} / \mathrm{kg}$. At the beginning, animals were resilient to eat the poisonous plant; after a week they accepted it, and when passing the time they ate it eagerly, to the point that when offered feed, they ate first I. carnea and then alfalfa.

The administration was suspended between days 43 and 60, when animals were euthanized. Control animals did not show any clinical signs or abnormalities. Experimental goats showed weight loss, hair coat, depression, difficulty to stand up, ataxia, hypermetria, wide-based stance, incordination of movements, intense tremors, spastic paresis, abnormal postural reactions, nystagmus, hyperreflexia, hypersensitivity to sound, head tilting, and equilibrium loss (Figures 2 and 3 ).

The progression of the intoxication signs varied considerably between animals. Appetite was maintained, in some occasions they even fed and drank in decubitus. The animals were euthanized immediately after presenting severe intoxication symptomatology. At necropsy, no significant macroscopic lesions were observed in studied animals.

Histopathological evaluation of animals treated with $I$. carnea revealed the presence of cytoplasmatic vacuolation, mainly in the perikaria of Purkinje cells, located between the granular and molecular layers of the cerebellum (Figure 4). The neurons had swollen, showing loss of cell structure, and eccentric nucleus. Loss of neurons was also observed. Moderate fine cy-

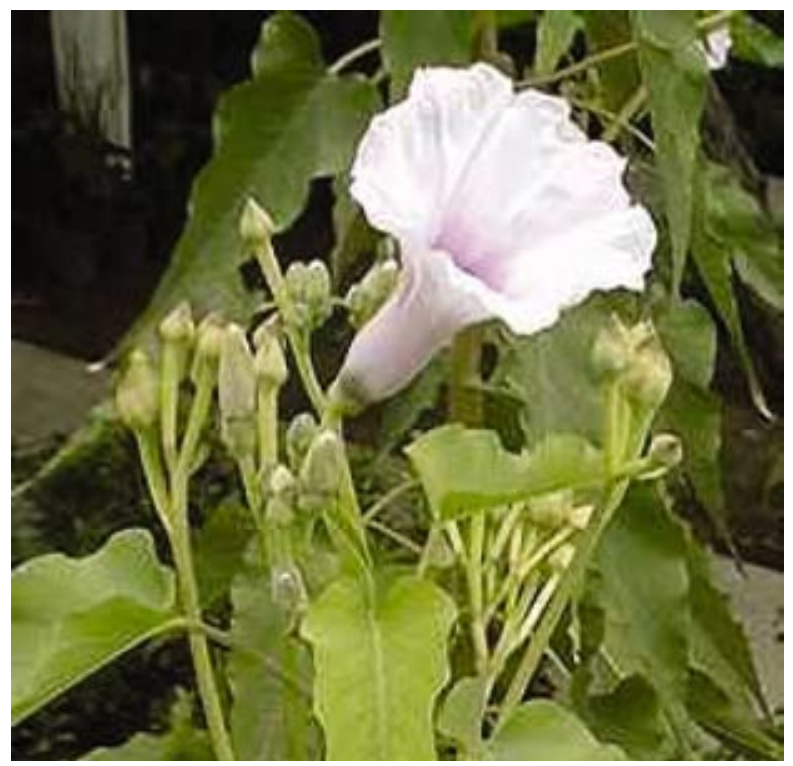

Figure 1. Ipomoea carnea var. fistulosa. 
toplasmic vacuolation was showed in neurons of the medulla oblongata (Figure 5). Those lesions were observed in all treated animals. The Nills substance was dispersed or absent and the neurons showed chromatolysis in poisoned animals.

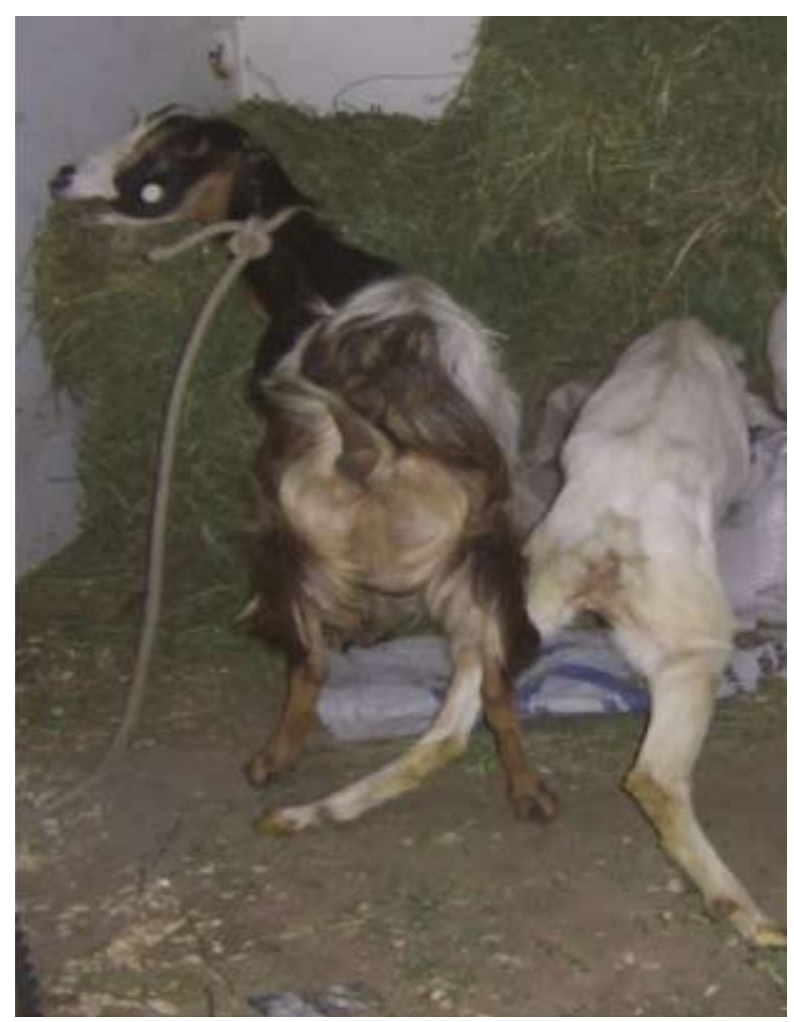

Figure 2. Goat (right) reveals abnormal posture and wide-based stances, due to lpomoea carnea consumption. Goat control (left) shows normal appearance.

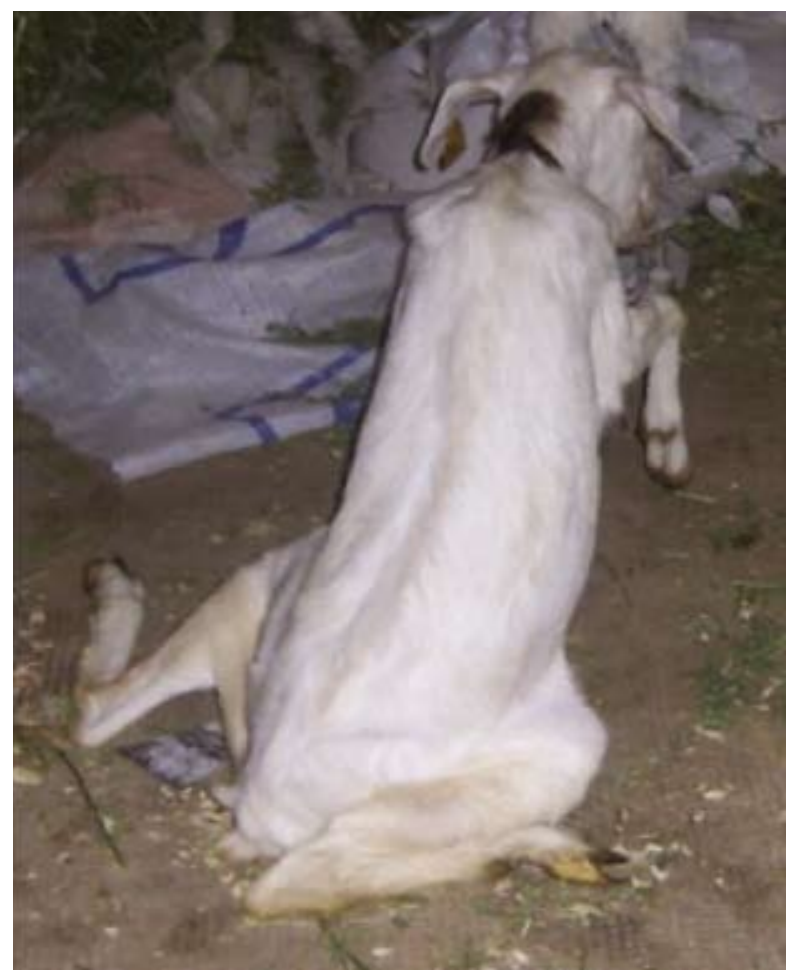

Figure 3. Goat inhability to stand up and conserve the equilibrium.

\section{DISCUSSION}

The preference for the consumption of I. carnea had been reported also in the intoxication by other swainsonine-contanining plants, including Swainsonine sp., Sida carpinifolia, and "locoweeds" ${ }^{4}$. Consumption of I. carnea in goats induces lysosomal storage disease resulting in cytoplasmatic vacuolation, mainly of me-

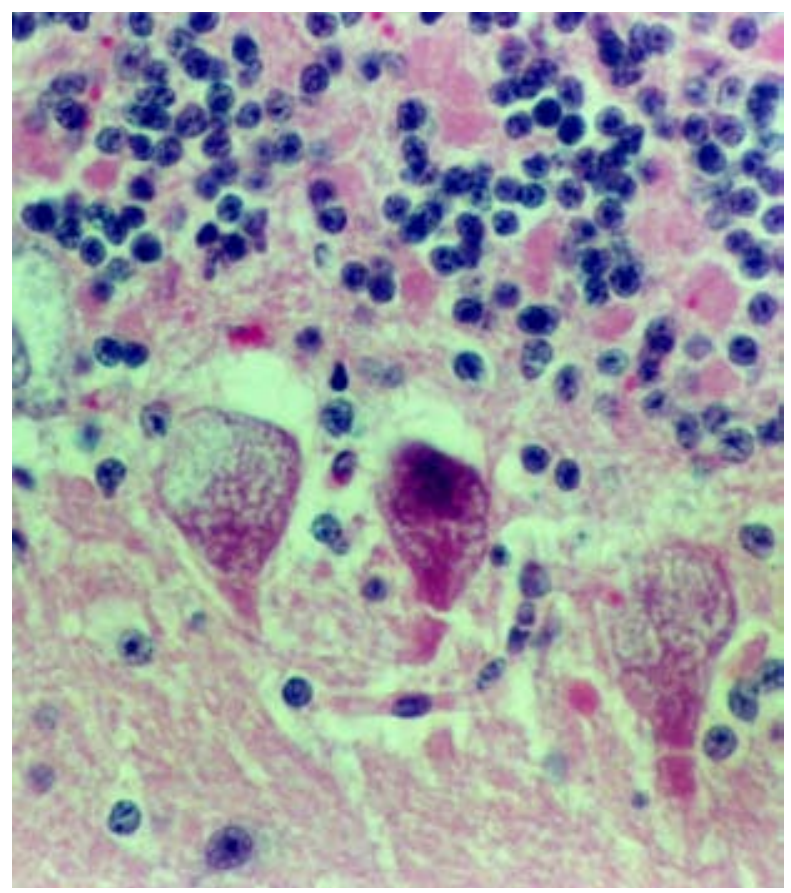

Figure 4. Cerebellum from intoxicated goat ( $53^{\circ}$ day). Note the presence of cytoplasmic vacuolation in Purkinje cells. H\&E stain, 40X.

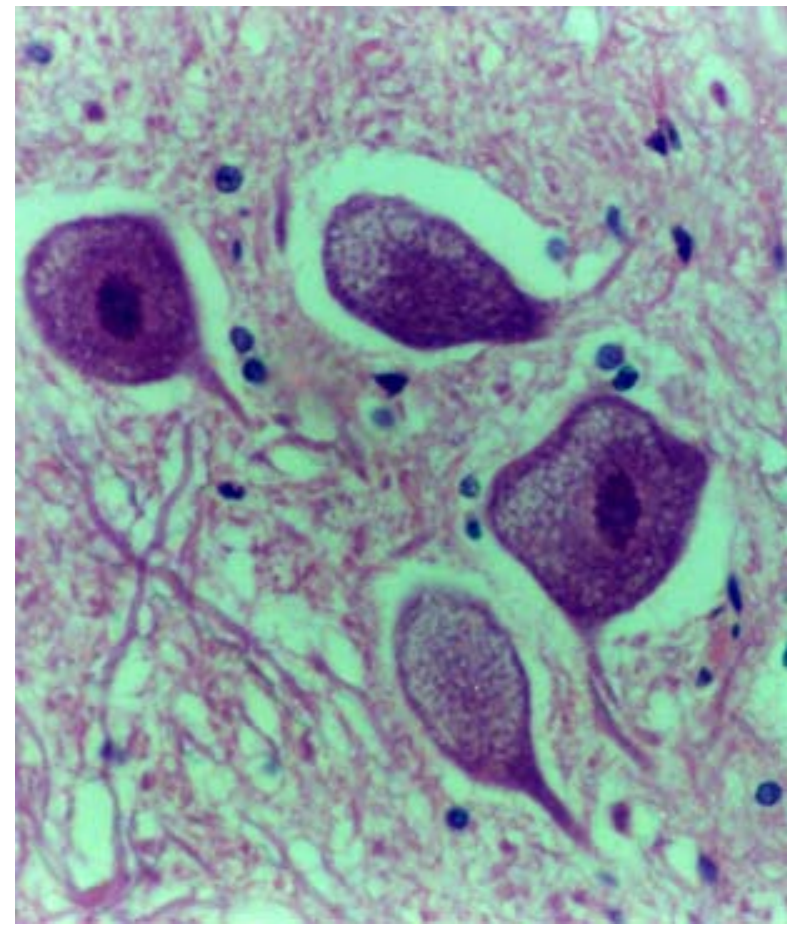

Figure 5. Medulla oblongata from intoxicated goat $\left(53^{\circ}\right.$ day). Note cytoplasmic vacuolation in neurons. H\&E stain, 40X. 
dulla oblongata and cerebellum. Similar lesions were reported by other authors in the same and other plants that contain swainsonine as alkaloid responsible of the intoxication ${ }^{2,4}$. It was communicated that leaves of $I$. carnea from Northeast of Argentina, contain swainsonine and calystegines ${ }^{5}$.

The present study showed that the poisoning in goats occurred after ingesting $50 \mathrm{~g} / \mathrm{kg}$ body weight daily for periods of 43-60 days. In experiment carried out in spring, intoxication occurred at 21 days from the beginning the plant consumption ${ }^{17}$. These results suggest that plant toxicity varies according to the time of the year; it has also been reported by other authors ${ }^{4}$. According to some researchers, levels of swansonine and calystegine superior to $0,001 \%$ would be probably toxic ${ }^{15}$. The illness also occurred in goats after consumption of $5 \mathrm{~g}$ of green plant per kg body weight per day for 5-107 trial days ${ }^{2,18,19}$.

The present study demonstrated that cerebellum is one of the main affected organs in the I. carnea intoxication. This organ processes information from other nervous areas, mainly spinal cord and sensory receptors, with the purpose to coordinate skeletal muscle movements. The functional unit of the cerebellum cortex are the Purkinje cells; these cells send inhibitory projections to the deep cerebellar nuclei. These neurons were severely affected in this intoxication, including necrosis in some of them ${ }^{4}$.

Equilibrium and postural movements are controlled by cerebellum, spinal cord and brain stem. Cerebellum is especially important in controlling the balance between agonist and antagonist muscles during rapid changes in body positions. It is impossible that in any instant during the quick movement the brain knows the exact position of the different body parts, but with appropriate neuronal circuits, it would be possible that cerebellum or certain brain portions would know the rapidity and direction in which a part of the body move. This is one of the main functions of the cerebellum ${ }^{13}$.

There are two feedback systems almost completely independent between the motor cortex and the cerebellum for the agonist and antagonist muscles regulation ${ }^{13}$. In this experience, cerebellar control would be affected. We observed that animals manifested intoxication symptoms as difficulty to stand up, ataxia, hypermetria, equilibrium loss, and often sternal recumbency.

In goats poisoned by I. carnea, other autor also reported cerebellar dysfunction. The clinical symptoms were consequence of the damage of the most of gabaergic neurons, and they coincide with those observed in this work ${ }^{1}$.

Medulla oblongata also showed cytoplasmic vacuoles in neurons, which possibly would difficult the transmission of the impulse from the medulla towards the brain ${ }^{13}$. In this experience, reactions that evidenced abnormalities in the sound stimuli, with hyper-sensitivity to sound, accompanied with abnormal postures and head tremors, were registered during the clinical examination to the vestibulocochlear nerve.
The vestibulocochlear nerve has two portions, the vestibular and cochlear nerves. Its function is to transmit sensorial signs from the ear interna, that it is related with the audition sense and equilibrium. Vestibular nerve is located in the ear interna and carries sensorial information, coordinating the movements and head orientation and participating in the static and dynamic equilibrium ${ }^{13}$. The efferent of vestibular nuclei are projected to the brain and spinal cord, both organs were affected in this experience.

Connections among brain, spinal cord, and vestibular nuclei, allow to coordinate the activity of extensor and flexor muscles, regulating the muscular tone and the anti-gravitational positions of the head. In this trial, poisoned goats showed abnormal head positions. The cochlear nerve is an exteroceptive nerve which function is carries the external sensitive stimuli ${ }^{13}$. Intoxicated goats showed an exaggerated answer to the sound stimuli possibly due to the lesion previously mentioned.

These findings show the CNS damages caused by the intoxication with I. carnea. It is necessary to complement this trial with a toxicological study of this lysosomal storage disease, because the plant is one of the most toxic of the Northeast of Argentina and it causes animal production important losses.

\section{REFERENCES}

1. Armién A. 2000. Vergleichende klinische und morphologische Untersuchungen zur spontanen und experimentellen Vergiftung durch Ipomoea fistulosa (Convolvulaceae) bei Ziegen. Tesis Doctoral, Justus-Liebig-Universität, Giessen, 212 p.

2. Armién AG, Tokarnia CH, Vargas Peixoto P, Frese K. 2007. Spontaneous and experimental glycoprotein storage disease of goats induced by Ipomoea carnea subsp fistulosa (Convolvulaceae). Vet Pathol 44: 170-84.

3. Austin DF, Huáman Z. 1996. A synopsis of Ipomoea (Convolvulaceae) in the Americas. Taxon 45: 3-38.

4. Barbosa RC, Riet-Correa F, Medeiros RM, Lima EF, Barros SS, Gimeno EJ, Molyneux RJ, Gardner DR. 2006. Intoxication by Ipomoea sericophylla and Ipomoea riedelii in goats in the state of Paraíba, Northeastern Brazil. Toxicon 47: 371-379.

5. Cholich L, Teibler G, Mussart N, Jorge N, Acosta O. 2008. Enfermedad de almacenamiento lisosomal en el cobayo. Aspectos histológicos del aparato digestivo y glándulas anexas. Anales XIV Congreso de la Asociación de Ciencias Morfológicas (Corrientes, Argentina) p. 100.

6. De Balogh K, Dimande AP, Van Der Lugt JJ, Molyneux RJ, Naudé TW, Welman WG. 1999. A lysosomal storage disease induced by Ipomoea carnea in goats in Mozambique. J Vet Diagn Invest 11: 266-273.

7. Gallo GG. 1987. Plantas tóxicas para el ganado en el cono sur de América, EUDEBA, Buenos Aires, p. 235.

8. Gardner D, Lee S, Molyneux R, Edgar J. 2003. Preparative isolation of swansonine from locoweed: extraction and purification procedures. Phytochem Anal 14: 259-266. 
9. Haraguchi M, Gorniak SL, Ikeda K, Minami Y, Kato A, Watson AA, Nash RJ, Molyneux RJ, Asano N. 2003. Alkaloidal components in the poisonous plants, Ipomoea carnea (Convolvulacea). J Agric Food Chem 51: 49955000 .

10. Hueza IM, Dagli ML, Gorniak SL, Paulino CA. 2003. Toxic effect of prenatal Ipomoea carnea administration to rats. Vet Hum Toxicol 45: 298-302.

11. Huxtable CR, Dorling PR, Walkley US. 1982. Onset and regression of neuroaxonal lesions in sheep with mannosidosis induced experimentally with swainsonine. Acta Neuropathol 58: 27-33.

12. Jolly RD, Walkley SU. 1997. Lysosomal storage disease of animals: an essay in comparative pathology. Vet Pathol 34: 527-548.

13. Kolb E. 1976. Fisiología Veterinaria, Acribia, Zaragoza, p. 948-1001.

14. Molyneux RJ, Pan YT, Goldmann A. 1993. Calystegins, a novel class of alkaloid glycosidase inhibitors. Arch Biochem Biophys 304: 81-88.

15. Molyneux R, Mckenzie R, O'Sullivan B. 1995. Identification of the glycosidase inhibitors swansonine and calystegine B2 in weir vine (Ipomoea sp aff. Calobra) and correlation with toxicity. J Nat Prod 58: 878-886.
16. Riet-Correa E, Mendez M. 2000. Plantas Tóxicas e Micotoxicoses, Ed. Gráfica Universitária-UFPEL, Pelotas (Brasil), p. 36-37.

17. Ríos E, Belmonte C, Rodríguez C, Ortiz l, Ciotti E, Bogado F, Acosta de Pérez O. 2005. Intoxicación con Ipomoea fistulosa (aguapié o mandiyurá) en cabras. Efectos sobre el hemograma e ionograma. Rev Vet 16: 21-24.

18. Srilatha C, Naidu NR, Rao PR. 1993. Haematological and biochemical studies in Ipomoea carnea plant toxicity in goats. J Vet Anim Sci 24: 146-148.

19. Srilatha C, Naidu NR, Rao PR. 1993. Symptomatology of Ipomoea carnea plant toxicity in goats. J Vet Anim Sci 24: 201-202.

20. Stegelmeier BL, Molyneux RJ, Elbein AD, James LF. 1995. The lesions of locoweed (Astragalus mollissimus), swainsonine, and castanospermine in rats. Vet Pathol 32: 289-298.

21. Tokarnia CH, Dobereiner J, Peixoto PV. 2002. Poisonous plants affecting livestock in Brazil. Toxicon 40: 16351660 . 